\title{
Potential Mechanisms for IgG4 Inhibition of Immediate Hypersensitivity Reactions
}

\author{
Louisa K. James ${ }^{1} \cdot$ Stephen J. Till ${ }^{2}$
}

Published online: 18 February 2016

(C) The Author(s) 2016. This article is published with open access at Springerlink.com

\begin{abstract}
IgG} 4$ is the least abundant IgG subclass in human serum, representing less than $5 \%$ of all IgG. Increases in IgG4 occur following chronic exposure to antigen and are generally associated with states of immune tolerance. In line with this, IgG4 is regarded as an anti-inflammatory antibody with a limited ability to elicit effective immune responses. Furthermore, IgG4 attenuates allergic responses by inhibiting the activity of IgE. The mechanism by which IgG4 inhibits IgE-mediated hypersensitivity has been investigated using a variety of model systems leading to two proposed mechanisms. First by sequestering antigen, IgG4 can function as a blocking antibody, preventing cross-linking of receptor bound IgE. Second IgG4 has been proposed to co-stimulate the inhibitory IgG receptor Fc $\gamma$ RIIb, which can negatively regulate FceRI signaling and in turn inhibit effector cell activation. Recent advances in our understanding of the structural features of human IgG4 have shed light on the unique functional and immunologic properties of IgG4. The aim of this review is to evaluate our current understanding of IgG4 biology and
\end{abstract}

This article is part of the Topical Collection on Immune Deficiency and Dysregulation

Stephen J. Till

stephen.till@kcl.ac.uk

Louisa K. James

louisa.james@kcl.ac.uk

1 Randall Division of Cell and Molecular Biophysics and MRC and Asthma UK Centre for Allergic Mechanisms of Asthma, King's College London, London SE1 1UL, UK

2 Division of Asthma, Allergy and Lung Biology, King's College London and Department of Allergy, Guy's and St. Thomas' NHS Foundation Trust, London SE1 9RT, UK reassess the mechanisms by which IgG4 functions to inhibit IgE-mediated allergic responses.

Keywords IgG4 $\cdot$ Hypersensitivity $\cdot$ Blocking antibodies . Allergy $\cdot$ Allergen immunotherapy $\cdot \operatorname{IgE}$

\section{Introduction}

The identification of four distinct subclasses of human IgG was first described during the 1960s, when they were designated as $\operatorname{IgG} 1, \operatorname{IgG} 2, \operatorname{IgG} 3$ and $\operatorname{IgG} 4$, based on their relative concentrations in human serum [1-3]. IgG4 was notable as the least abundant $\operatorname{IgG}$ subclass with an average serum concentration of $0.4 \mathrm{mg} / \mathrm{ml}$, compared to $8 \mathrm{mg} / \mathrm{ml}$ for IgG1. In addition, unlike the other IgG subclasses, IgG4 is unable to fix complement or precipitate antigens. IgG4 is comprised of two identical $50-\mathrm{kDa}$ heavy chains each consisting of four distinct immunoglobulin domains ( $\mathrm{VH}, \mathrm{CH} 1, \mathrm{CH} 2$ and $\mathrm{CH} 3)$ and two identical $25-\mathrm{kDa}$ light chains each consisting of two immunoglobulin domains (VL and CL). The 12 amino acid hinge region between $\mathrm{CH} 1$ and $\mathrm{CH} 2$ provides mobility of the variable $\mathrm{Fab}$ regions in relation to the $\mathrm{Fc}$ region, facilitating binding of antigen. All of the IgG subclasses share a high degree of sequence homology, but key differences in the hinge region and $\mathrm{C} \gamma 2$ domain give rise to important variations in effector function.

IgG antibodies interact with immune cells through binding to $\mathrm{Fc} \gamma$ receptors expressed on cell surfaces [4•]. With the exception of the neonatal $\mathrm{Fc} \gamma$ receptor ( $\mathrm{Fc} \gamma \mathrm{Rn}$ ), which binds at the $\mathrm{C} \gamma 2-\mathrm{C} \gamma 3$ interface and functions primarily to transport $\mathrm{IgG}$ across placental and mucosal surfaces, all $\mathrm{Fc} \gamma$ receptors bind at the $\mathrm{N}$-terminus of $\mathrm{C} \gamma 2$. There are seven $\mathrm{Fc} \gamma$ receptors in humans (Table 1); Fc $\gamma$ RI has the highest overall affinity for IgG and can bind monomeric antibody. This high affinity 
means that Fc $\gamma \mathrm{RI}$ is saturated with $\mathrm{IgG}$, although similar to the high affinity IgE receptor FceRI, signaling only occurs following antigen cross-linking [5]. The other Fc $\gamma$ receptors generally have lower affinity (100-1000-fold less) for IgG subclasses and hence bind only to immune complexes and not to monomeric antibody.

IgG4 binds to all of the Fc $\gamma$ receptors with the exception of Fc $\gamma$ RIIIb (Table 1), which contains a membrane anchored GPI domain and thus cannot induce intracellular signaling [6]. Fc $\gamma$ RI and Fc $\gamma$ RIIIa both associate with the common $\gamma$ chain, which contains an intracellular immunoreceptor tyrosine-based activation motif (ITAM), driving cellular activation upon receptor engagement. Fc $\gamma$ RIIa and Fc $\gamma$ RIIc are single-chain activating receptors and also possess an ITAM in their intracellular domains. Signaling through activated Fc $\gamma$ receptors promotes a range of effector functions including internalization of Fc-bound immune complexes, enhanced antigen-presentation, antibody-dependent cell-mediated cytotoxicity (ADCC) and cellular activation $[7 \cdot, 8]$. In contrast, Fc $\gamma$ RIIb is a single-chain inhibitory receptor, the only inhibitory $\mathrm{Fc} \gamma$ receptor in humans, possessing an immunoreceptor tyrosine-based inhibition motif (ITIM) in the intracellular domain. IgG4 is the only IgG subclass that can bind with equal affinity to both $\mathrm{Fc} \gamma \mathrm{RIIb}$ and the activating receptors. Co-ligation of Fc $\gamma$ RIIb with activating Fc $\gamma$ receptors results in inhibition of effector cell responses [9]. Fc $\gamma$ RIIb also plays an important role in regulation of $\mathrm{B}$ cell activity and plasma cell survival [10].

The crystal structure of human IgG4 Fc was first solved in 1997 in complex with an IgM rheumatoid factor [11]. More recently, a higher resolution structure of IgG4-Fc was solved, providing further insights into the unique structural features of IgG4 [12••]. Notably, conformational differences in two key loop structures in the $\mathrm{C} \gamma 2$ domain of IgG4 compared to IgG1 provide a structural basis for the lower binding affinity of IgG4 to some of the Fc $\gamma$ receptors and the inability of $\mathrm{IgG} 4$ to bind the complement component $\mathrm{C} 1 \mathrm{q}$.

\section{Fab Arm Exchange}

Cysteine residues in the hinge region of IgG4 result in intra-heavy chain disulphide bonds, as opposed to the inter-heavy chain bonds present in the other IgG subclasses. In addition, a key amino acid substitution in the $\mathrm{C} \gamma 3: \mathrm{C} \gamma 3$ interface weakens the domain interactions. Under reducing conditions, the combined effect allows dissociation of the two heavy chains of human IgG4 into half-molecules [13]. Re-association of half-molecules originating from different IgG4 antibodies results in 'bi-specific' monovalent antibodies. IgG4 antibodies that have undergone this process are consequently unable to undergo antigen cross-linking to form immune complexes. Analysis of serum from healthy human subjects revealed that $20-30 \%$ of monomeric IgG4 contained both $\mathrm{K}$ and $\lambda$ light chains within the same molecule, demonstrating that $\mathrm{Fab}$ arm exchange occurs in vivo in a substantial fraction of IgG4 [14•].

\section{IgG4 Production}

Naïve B cells express IgM as a monomeric membrane-bound $B$ cell receptor (BCR). Activation of naïve B cells through the $\mathrm{BCR}$ can lead to rearrangement of the immunoglobulin heavy chain locus through class switch recombination. This results in the expression of a different 'switched' isotype (IgG, IgA or $\mathrm{IgE}$ ), dependent on additional signals provided by cytokines. Class switch recombination to IgG4 depends on the production of the Th2 cytokines IL-4 and IL-13, along with ligation of CD40 [15, 16]. These same signals (IL-4 plus CD40L) classically drive class switch recombination to $\mathrm{IgE}$, the primary effector antibody involved in allergic disease [17]. There is a clear biological relationship between IgG4 and IgE production, although the molecular mechanisms that dictate recombination to IgG4 versus IgE have yet to be fully elucidated [18]. The addition of IL-10 [19] or IL-21 [20] to in vitro

Table 1 Cellular expression and relative binding affinities of human Fc $\gamma$ receptors

\begin{tabular}{|c|c|c|c|c|c|}
\hline Receptor & Cellular expression & IgG1 & IgG2 & IgG3 & IgG4 \\
\hline $\mathrm{Fc} \gamma \mathrm{RI} / \mathrm{CD} 64$ & Monocytes, macrophages, DC, neutrophils ${ }^{\mathrm{a}}$, mast cells ${ }^{\mathrm{a}}$ & ++++ & - & ++++ & ++++ \\
\hline $\mathrm{Fc} \gamma \mathrm{RIIa} / \mathrm{CD} 32 \mathrm{a}$ & Monocytes, macrophages, DC, basophils, mast cells, eosinophils, platelets & +++ & ++ & +++ & ++ \\
\hline Fc $\gamma$ RIIb/CD32b & B cells, DC, basophils, neutrophils subsets of monocytes and macrophages & + & - & ++ & + \\
\hline $\mathrm{Fc} \gamma \mathrm{RIIc} / \mathrm{CD} 32 \mathrm{c}$ & NK cells, monocytes, macrophages and neutrophils & + & - & ++ & + \\
\hline Fc $\gamma$ RIIIa/CD16a & Natural killer (NK) cells, monocytes and macrophages & +++ & $+/-$ & ++++ & $+/-$ \\
\hline $\mathrm{Fc} \gamma \mathrm{RIIIb} / \mathrm{CD} 16 \mathrm{~b}$ & Neutrophils subsets of basophils & +++ & - & +++ & - \\
\hline $\mathrm{Fc} \gamma \mathrm{Rn}$ & Monocytes, macrophages, DC, neutrophils, epithelial cells, endothelial cells & ++++ & ++++ & ++++ & ++++ \\
\hline
\end{tabular}

There are two polymorphic variants of Fc $\gamma$ RIIa $(131 \mathrm{H}$ and 131R) with similar binding properties. Fc $\gamma$ RIIIa has two polymorphic variants $(158 \mathrm{~V}$ and $158 \mathrm{~F})$. IgG2 and IgG4 bind only to Fc $\gamma \mathrm{RIII}^{158 \mathrm{~V}}$ and only as immune complexes, whereas IgG1 and IgG3 bind to both variants with high affinity [6]. IgG binding to $\mathrm{Fc} \gamma \mathrm{Rn}$ only occurs at $\mathrm{pH}<6.5$ but it binds to all $\mathrm{IgG}$ subclasses [60]

${ }^{\mathrm{a}}$ Induced following activation 
cultures can enhance or suppress the production of both IgG4 and IgE depending on the conditions under which B cells are stimulated. Although IL-10-producing B cells are reported to produce increased amounts of $\mathrm{IgG} 4$ in culture compared to IL-10 ${ }^{-}$B cells [21], $\mathrm{IgG}^{+} \mathrm{B}$ cells express equivalent amounts of IL-10 to their $\operatorname{IgG} 1^{+}$counterparts [22••]. This suggests that while IL-10 can influence the production of $\mathrm{IgG} 4, \mathrm{IgG}^{+} \mathrm{B}$ cells themselves are not the major source of this cytokine. Circulating $\mathrm{IgG}^{+} \mathrm{B}$ cells from healthy individuals have a similar but distinct phenotype to $\operatorname{IgG}^{+}$B cells: they lack surface IgD but express CD27, consistent with the phenotype of class-switched memory B cells [22••]. Expression of the complement receptor CD21 (CR2) is lower on $\mathrm{IgG}^{+} \mathrm{B}$ cells compared to $\operatorname{IgG} 1^{+} \mathrm{B}$ cells from the same individuals. CD21 forms part of the $\mathrm{B}$ cell receptor-signaling complex along with CD19 and CD81 and also has an important role in internalization of immune complexes [23]. Hence, lower expression of CD21 may result in reduced responsiveness to antigen and/or immune complexes. Furthermore, Lighaam and colleagues [22••] reported increased expression of the $\mathrm{IgE}$ receptor, CD23 (FceRII) on IgG4 ${ }^{+}$versus $\mathrm{IgG}^{+}{ }^{+} \mathrm{B}$ cells. CD23 expression is up-regulated by IL-4, an important switch factor for $\mathrm{IgG} 4$, again highlighting the close association between IgG4 and $\mathrm{IgE}$.

\section{IgG4 and the Modified Th2 Response}

An important feature of IgG4 production is the association with high-dose chronic antigen exposure. The production of allergen-specific IgG4 is linked to the 'modified Th2 hypothesis', whereby an allergen-driven Th2 response in which IgG4 dominates and $\mathrm{IgE}$ is absent results in protection from immediate hypersensitivity [24]. This was first described by Platts-Mills and colleagues who demonstrated that children exposed to high concentrations of the major cat allergen, Fel d 1, had high titers of Fel d 1-specific IgG4 and were clinically tolerant (ie not cat allergic) [25]. Similarly, high titers of allergen-specific IgG4 are observed following chronic exposure to other exogenous antigens including occupational allergens [26] and bee venom [27]. Thus, the balance between IgG4 and IgE production appears to critically influence the development of allergic hypersensitivity versus immune tolerance. Importantly, studies of IgG4-induced antibody responses in allergen immunotherapy (AIT) demonstrate that IgG4 is capable of directly inhibiting the activity of IgE.

\section{IgG4 and Allergen Immunotherapy}

AIT is an effective treatment for IgE-mediated allergy and induces long-term clinical tolerance, associated with increases in IL-10-producing T regulatory cells and reductions in basophil reactivity [28]. The observation that IgG4 responses are associated with chronic high-dose natural allergen exposure is consistent with the effect of AIT - involving repeated administration of high-dose subcutaneous, sublingual or oral allergen over years - in inducing allergen-specific IgG4 [29-31]. The concept that treatment-induced IgG antibodies could provide protection from immediate hypersensitivity emerged early in the history of AIT. Pre-dating even the discovery of IgE, Cooke and Loveless demonstrated that post-immunotherapy serum could inhibit in vivo Prausnitz-Küstner reactions [32]. In 1982, Golden et al. demonstrated that titers of venomspecific IgG were significantly higher in patients who were successfully treated with venom immunotherapy, whereas treatment failure was associated with lower levels of specific IgG [33]. This led to the theory that specific IgG levels could correlate with the clinical response to treatment. During this time, it was established that despite initial low levels in serum, AIT appeared to stimulate marked increases in allergenspecific IgG4 [34]. However, data from certain clinical trials raised doubts regarding the relevance of allergen-specific IgG4 to the clinical benefit of AIT since high levels of allergen-specific IgG4 were associated with treatment failure rather than success [35].

\section{Inhibition of IgE Activity by IgG4}

Definitive evidence that $\operatorname{IgG}$ is able to inhibit IgE activity was provided by Van Neerven and colleagues who reported that AIT-induced IgG could inhibit IgE-facilitated allergen presentation (IgE-FAP) by B cells to T cells in vitro [36]. Later similar studies went on to show that this 'blocking activity' co-eluted with IgG4 [37, 38]. IgE-FAP depends on the binding of immune complexes formed of allergen and specific IgE to the low-affinity IgE receptor CD23 (FceRII). Capture of IgE-allergen complexes by CD23-expressing antigenpresenting cells results in internalization and processing of the allergen-IgE-receptor complex with subsequent presentation of allergen-derived peptides to T cells [39]. The ability of IgG4 antibodies to inhibit this process relies entirely on the affinity, specificity and quantity of the blocking antibody, regardless of isotype or subclass [40, 41•]. Conventional subcutaneous immunotherapy induces significant increases in allergen-specific IgG4 6-8 weeks following the start of treatment [29]. This corresponds with the appearance of IgE-FAP inhibitory activity in serum but is preceded by increases in allergen-driven IL-10 production by peripheral blood mononuclear cells. The functional inhibitory activity of IgG4 appears to relate more closely to the clinical efficacy of AIT than absolute levels in serum, which may explain why levels of IgG4 often correlate poorly with clinical responses. In a randomized double-blind placebo controlled trial of subcutaneous grass pollen immunotherapy, continued clinical remission 2 years after treatment withdrawal was accompanied by persisting inhibitory antibody activity in serum against IgE-FAP [38]. Although the levels of serum allergen-specific 
IgG4 fell to near pretreatment values during the 2 years of treatment withdrawal, depletion experiments identified $\operatorname{IgG} 4$ as the main source of the continuing inhibitory activity. This study indicates that the activity but not quantity of IgG4 antibodies per se is the main determinant of clinically relevant $\operatorname{IgE}$ inhibition (Fig. 1).

In addition to inhibiting CD23-dependent IgE activity, IgG4 can also block the effects of IgE signaling through FceR1, and in turn inhibit immediate hypersensitivity. For example, IgG4 purified from the serum of an immunotherapy-treated individual inhibited IgE-mediated basophil degranulation, which depends on cross-linking of high-affinity $\operatorname{IgE}$ receptor (FcERI) -bound $\operatorname{IgE}$ [42]. The ability of IgG4 to inhibit FceRI-dependent activity of IgE has been proposed to arise through two possible mechanisms; either through direct competition for allergen with receptor-bound $\operatorname{IgE}$ and/or through simultaneous binding of IgG4 to the inhibitory Fc $\gamma$ RIIb. A high-affinity monoclonal IgG4 antibody specific for the grass pollen allergen $\mathrm{Phl} p 7$ was able to inhibit IgE-mediated basophil degranulation in vitro [43]. In order to determine whether this activity was subclass-dependent, a panel of antibodies with identical specificity but different subclasses, namely $\operatorname{IgG} 1, \operatorname{IgG} 2, \operatorname{IgG} 3, \operatorname{IgA} 1$ and $\operatorname{IgA} 2$, was generated [41•]. The antibody specificity was found to be the critical determinant of the inhibitory activity, since each subclass was able to block basophil activation to an equal degree. Thus, any antibody isotype with sufficient affinity for allergen has the potential to effectively prevent cross-linking of $\operatorname{IgE}$ receptors though competition with $\operatorname{IgE}$ for allergen binding.

\section{IgG4 and Fe $\gamma$ RIIb-Mediated Inhibition of IgE}

Using a bi-specific antibody, Kepley and colleagues demonstrated that cross-linking of Fc $\gamma$ RIIb and FceRI inhibits IgE-mediated basophil activation [44]. The role of Fc $\gamma$ RIIb in the inhibitory effect of AIT serum on basophil degranulation has been the subject of conflicting reports in the literature. In two independent studies using similar methodologies, the inhibitory activity of AIT serum on basophil activation was investigated by pre-incubation of basophils with antibodies to block human Fc $\gamma$ RII. Whereas one study found that pre-incubation attenuated the inhibitory effect of AIT serum leading to increased basophil activation [45], the other study reported that Fc $\gamma$ RII blockade had no effect on the inhibition of IgE-mediated basophil degranulation by AIT serum despite successful inhibition of IgG complex binding [46]. These two studies used different anti-Fc $\gamma$ RII antibody clones, although neither was able to discriminate between the activating (Fc $\gamma$ RIIa) and inhibitory (Fc $\gamma$ RIIb)
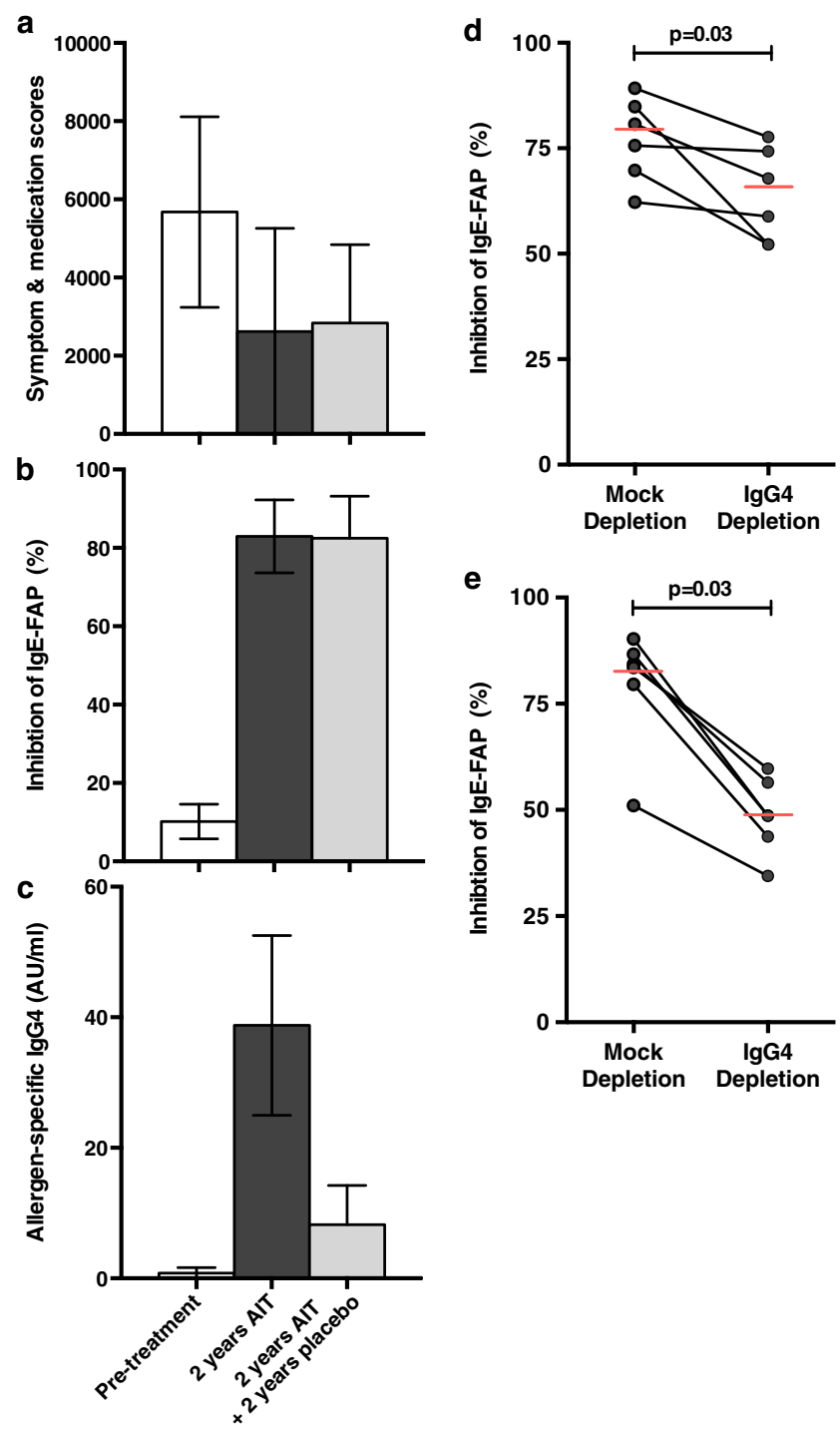

Fig. 1 Continued reduction in symptom and medication scores 2 years after withdrawal of grass pollen immunotherapy is accompanied by persisting IgG4-mediated inhibitory activity against IgE-FAP. a Symptom and medication scores at baseline, after 2 years of allergen immunotherapy and 2 years after stopping treatment. b Inhibition of IgE-FAP by sera taken at baseline, after 2 years of allergen immunotherapy and 2 years after stopping treatment. c Serum grass pollen-specific IgG4 measured by ELISA at baseline, after 2 years of allergen immunotherapy and 2 years after stopping treatment. d Inhibition of IgE-FAP by mock-depleted or IgG4-depleted serum taken after 2 years of allergen immunotherapy. e Inhibition of IgE-FAP by mock-depleted or IgG4-depleted serum taken 2 years after stopping treatment. Figure reproduced with permission from Reference 38

receptors expressed by human basophils. The direct effects of these antibodies on basophil function, e.g. activation by signaling through Fc $\gamma$ RIIa, were not investigated but may have influenced the experimental outcomes. A further single report used two monoclonal antibodies selective for Fc $\gamma$ RIIa and $\mathrm{Fc} \gamma \mathrm{RIIb}$, respectively, to assess the role of these receptors in IgG-mediated inhibition of basophil reactivity [47]. Intriguingly, the authors found 
that blocking either Fc $\gamma$ RIIa or Fc $\gamma$ RIIb attenuated the inhibitory activity of IgG from AIT serum, although as with previous studies, the direct effect of these monoclonal antibodies on basophil activation was not assessed [47].

The potential for interaction of allergen-specific IgG4 and Fc $\gamma$ RIIb to result in effective inhibition of FceRI signaling remains uncertain. Using surface plasmon resonance, Bruhns and colleagues found that $\mathrm{IgG} 4$ bound to Fc $\gamma$ RIIb with moderate affinity $\left(K_{A} 2 \times 10^{5} \mathrm{M}^{-1}\right)$ and when IgG4 antibodies were aggregated as $\mathrm{F}\left(\mathrm{ab}^{\prime}\right)_{2}$ complexes, binding to Fc $\gamma \mathrm{RIIb}$ was detected on cell surfaces [6]. However, human IgG4 does not precipitate antigen and forms only small immune complexes compared to IgG1 [48], likely due to the dynamic process of Fab arm exchange [49]. This may have significant functional consequences for interactions between $\mathrm{IgG} 4$ and Fc $\gamma$ RIIb, which have yet to be examined experimentally. Furthermore, the potential biological relevance of this pathway must also be considered, since although Fc $\gamma$ RIIb is constitutively expressed by basophils, expression on mast cells is variable depending on tissue distribution; while peripheral blood [50], cord-blood derived [51] and synovial mast cells [52] all express Fc $\gamma$ RIIb, expression has not been demonstrated on human skin mast cells [53] or intestinal mast cells from most individuals [54]. Therefore, at least in the skin and intestine, the potential relevance of IgG-mediated inhibition of mast cell activation through Fc $\gamma$ RIIb pathways must be questioned.

\section{Conclusions}

IgG4 is closely associated to the production of $\operatorname{IgE}$ and therefore has relevance to the study of allergic disease. Absolute levels of IgG4 often fail to correlate with clinical tolerance, although absolute levels of IgE are similarly poorly predictive of disease severity. Nonetheless, the biological activity of $\mathrm{IgG} 4$, in particular the potent inhibition of IgE-mediated basophil/mast cell activation and antigen presentation, suggest that this unique subclass is indeed relevant to disease expression. IgG4 has a long association with tolerance to aeroallergens, both in studies of allergen immunotherapy and the so-called modified Th2 response. An accumulating body of literature also supports a potential wider role for IgG4 in oral immunotherapy studies of food allergy [55] and also in natural tolerance to food allergens [56-59]. Experimental approaches need to be developed to address unresolved questions concerning IgG4 biology, such as identification of factors that regulate $\mathrm{IgG} 4$ versus IgE responses. Understanding the precise molecular determinants that control the fate of IgG4 versus IgE switching could highlight therapeutic targets for prevention of allergy and promotion of clinical tolerance.

\section{Compliance with Ethical Standards}

Conflict of Interest Drs. Till and James declare no conflicts of interest.

Human and Animal Rights and Informed Consent This article does not contain any studies with human or animal subjects performed by any of the authors.

Open Access This article is distributed under the terms of the Creative Commons Attribution 4.0 International License (http:// creativecommons.org/licenses/by/4.0/), which permits unrestricted use, distribution, and reproduction in any medium, provided you give appropriate credit to the original author(s) and the source, provide a link to the Creative Commons license, and indicate if changes were made.

\section{References}

Papers of particular interest, published recently, have been highlighted as:

- Of importance

•- Of major importance

1. Terry WD, Fahley JL, Steinberg AG. GM and INV factors in subclasses of human IgG. J Exp Med. 1965;122(6):1087-102.

2. Grey HM, Kunkel HG. H chain subgroups of myeloma proteins and normal 7S $\gamma$-globulin. J Exp Med. 1964;120:253.

3. Terry WD, Fahey JL. Subclasses of human 7S $\gamma$ globulin based on differences in the heavy polypeptide chains. Science. 1964;146:400.

4. Bruhns P, Jönsson F. Mouse and human FcR effector functions. Immunol Rev. 2015;268:25-51. An up-to-date literature review describing the properties and effector functions of $\mathrm{Fc}$ receptors in mouse and humans.

5. Nimmerjanh F, Ravtech JV. Fc $\gamma$ receptors as regulators of immune responses. Nat Rev Immunol. 2008;8:34-47.

6. Bruhns P, Iannascoli B, England P, Mancardi DA, Fernandez N, Jorieux S, et al. Specificity and affinity of human Fcgamma receptors and their polymorphic variants for human $\operatorname{IgG}$ subclasses. Blood. 2009;113:3716-25.

7. Vidarsson G, Dekkers G, Rispens T. IgG subclasses and allotypes: from structure to effector functions. Front Immunol. 2014;5:520. A comprehensive review of IgG subclasses and recent advances in the field.

8. Park J-G, Isaacs RE, Chien P, Schreiber AD. In the absence of other Fc receptors, FcgRIIIA transmits a phagocytic signal that requires the cytoplasmic domain of its g subunit. J Clin Invest. 1993;92:1967-73.

9. Daëron M, Jaeger S, Du Pasquier L, Vivier E. Immunoreceptor tyrosine-based inhibition motifs: a quest in the past and future. Immunol Rev. 2008;224:11-43.

10. Daëron M, Latour S, Malbec O, Espinosa E, Pina P, Pasmans S, et al. The same tyrosine-based inhibition motif, in the intracytoplasmic domain of Fc gamma RIIB, regulates negatively BCR-, TCR-, and FcR-dependent cell activation. Immunity. 1995;3(5):635-46.

11. Corper AL, Sohi MK, Bonagura VR, Steinitz M, Jefferis R, Feinstein A, et al. Structure of human IgM rheumatoid factor Fab bound to its autoantigen $\operatorname{IgG~Fc}$ reveals a novel topology of antibody-antigen interaction. Nat Struct Biol. 1997;4:374-81. 
12.• Davies AM, Rispens T, Ooijevaar-de Heer P, Gould HJ, Jefferis R, Aalberse RC, et al. Structural determinants of unique properties of human IgG4-Fc. J Mol Biol. 2014;426:630-44. This recent report describes a high-resolution crystal structure of human IgG4-Fc which provides a unique biological insight into its biological properties

13. Rispens T, den Bleker TH, Aalberse RC. Hybrid IgG4/IgG4 Fc antibodies form upon 'Fab-arm' exchange as demonstrated by SDS-PAGE or size-exclusion chromatography. Mol Immunol. 2010;47:1592-4.

14. Young E, Lock E, Ward DG, Cook A, Harding S, Wallis GL. Estimation of polyclonal IgG4 hybrids in normal human serum. Immunology. 2014;142:406-13. By analysing the proportions of IgG4 $\kappa$, IgG4 $\lambda$ and IgG4 $\kappa / \lambda$ in normal human polyclonal serum, this report demonstrates that hybrid IgG4 molecules constitute a substantial portion of the normal IgG4 pool.

15. Lundgren M, Persson U, Larsson P, Magnusson C, Smith CI, Hammarström L, et al. Interleukin 4 induces synthesis of $\operatorname{IgE}$ and IgG4 in human B cells. Eur J Immunol. 1989;19:1311-5.

16. Punnonen J, Aversa G, Cocks BG, McKenzie AN, Menon S, Zurawski $\mathrm{G}$, et al. Interleukin 13 induces interleukin 4independent IgG4 and IgE synthesis and CD23 expression by human B cells. Proc Natl Acad Sci U S A. 1993;90:3730-4.

17. Gould HJ, Sutton BJ. IgE in allergy and asthma today. Nat Rev Immunol. 2008;8:205-17.

18. Agresti A, Vercelli D. c-Rel is a selective activator of a novel IL-4/ CD40 responsive element in the human Ig gamma4 germline promoter. Mol Immunol. 2002;38:849-59.

19. Jeannin P, Lecoanet S, Delneste Y, Gauchat JF, Bonnefoy JY. IgE versus IgG4 production can be differentially regulated by IL-10. J Immunol. 1998;160:3555-61.

20. Wood N, Bourque K, Donaldson DD, Collins M, Vercelli D, Goldman SJ, et al. IL-21 effects on human IgE production in response to IL-4 or IL-13. Cell Immunol. 2004;231:133-45.

21. van de Veen W, Stanic B, Yaman G, Wawrzyniak M, Söllner S, Akdis DG, et al. IgG4 production is confined to human IL-10producing regulatory $\mathrm{B}$ cells that suppress antigen-specific immune responses. J Allergy Clin Immunol. 2013;131:1204-12.

22.• Lighaam LC, Vermeulen E, Bleker T, Meijlink KJ, Aalberse RC, Barnes E, et al. Phenotypic differences between IgG4+ and IgG1+ $\mathrm{B}$ cells point to distinct regulation of the IgG4 response. J Allergy Clin Immunol. 2014;133:267-70. This is the first report to isolate IgG4+ B cells from human peripheral blood by flow cytometry. The authors identified important differences in the phenotype of IgG4+ B cells compared to IgG1+ B cells from the same individuals, which may relate to the distinct biological properties of IgG4.

23. Roozendaal R, Carroll MC. Complement receptors CD21 and CD35 in humoral immunity. Immunol Rev. 2007;219:157-66.

24. Platts-Mills TA, Woodflok JA, Erwin EA, Aalberse R. Mechanisms of tolerance to inhalant allergens: the relevance of a modified Th2 response to allergens from domestic animals. Springer Semin Immunopathol. 2004;25:271-9.

25. Platts-Mills T, Vaughan J, Squillace S, Woodfolk J, Sporik R. Sensitisation, asthma, and a modified Th2 response in children exposed to cat allergen: a population-based cross-sectional study. Lancet. 2001;357:752-6.

26. Matsui EC, Diette GB, Krop EJ, Aalberse RC, Smith AL, CurtinBrosnan J, et al. Mouse allergen-specific immunoglobulin $\mathrm{G}$ and immunoglobulin G4 and allergic symptoms in immunoglobulin Esensitized laboratory animal workers. Clin Exp Allergy. 2005;35: $1347-53$

27. Aalberse RC, Van der Gaag R, Van Leeuwen J. Serologic aspects of IgG4 antibodies. I. Prolonged immunization results in an IgG4restricted response. J Immunol. 1983;130:722-6.
28. James LK, Durham SR. Update on mechanisms of allergen injection immunotherapy. Clin Exp Allergy. 2008;38:1074-88.

29. Francis JN, James LK, Paraskevopoulos G, Wong C, Calderon MA, Durham SR, et al. Grass pollen immunotherapy: IL-10 induction and suppression of late responses precedes IgG4 inhibitory antibody activity. J Allergy Clin Immunol. 2008;121:1120-5.

30. Scadding GW, Shamji MH, Jacobson MR, Lee DI, Wilson D, Lima MT, et al. Sublingual grass pollen immunotherapy is associated with increases in sublingual Foxp3-expressing cells and elevated allergen-specific immunoglobulin G4, immunoglobulin A and serum inhibitory activity for immunoglobulin E-facilitated allergen binding to B cells. Clin Exp Allergy. 2010;40:598-606.

31. Vickery BP, Lin J, Kulis M, Fu Z, Steele PH, Jones SM, et al. Peanut oral immunotherapy modifies IgE and IgG4 responses to major peanut allergens. J Allergy Clin Immunol. 2013;131:128-34.

32. Cooke RA, Loveless M, Stull A. Studies on immunity in a type of human allergy (hay fever): serological response of non-sensitive individuals to pollen injections. J Exp Med. 1937;66:689-96.

33. Golden DB, Meyers DA, Kagey-Sobotka A, Valentine MD, Lichtenstein LM. Clinical relevance of the venom-specific immunoglobulin $\mathrm{G}$ antibody level during immunotherapy. J Allergy Clin Immunol. 1982;69:489-93.

34. Devey ME, Wilson DV, Wheeler AW. The IgG subclasses of antibodies to grass pollen allergens produced in hay fever patients during hyposensitization. Clin Allergy. 1976;6:227-36.

35. Djurup R, Malling HJ. High IgG4 antibody level is associated with failure of immunotherapy with inhalant allergens. Clin Allergy. 1987;17:459-68.

36. van Neerven RJ, Wikborg T, Lund G, Jacobsen B, Brinch-Nielsen A, Arnved J, et al. Blocking antibodies induced by specific allergy vaccination prevent the activation of $\mathrm{CD} 4+\mathrm{T}$ cells by inhibiting serum-IgE-facilitated allergen presentation. J Immunol. 1999;163: 2944-52.

37. Nouri-Aria KT, Wachholz PA, Francis JN, Jacobson MR, Walker SM, Wilcock LK, et al. Grass pollen immunotherapy induces mucosal and peripheral IL-10 responses and blocking IgG activity. J Immunol. 2004;172(5):3252-9.

38. James LK, Shamji MH, Walker SM, Wilson DR, Wachholz PA, Francis JN, et al. Long-term tolerance after allergen immunotherapy is accompanied by selective persistence of blocking antibodies. $\mathrm{J}$ Allergy Clin Immunol. 2011;127:509-16.

39. Wilcock LK, Francis JN, Durham SR. IgE-facilitated antigen presentation: role in allergy and the influence of allergen immunotherapy. Immunol Allergy Clin N Am. 2006;26:333-47.

40. Holm J, Willumsen N, Würtzen PA, Christensen LH, Lund K. Facilitated antigen presentation and its inhibition by blocking IgG antibodies depends on IgE repertoire complexity. J Allergy Clin Immunol. 2011;127:1029-37.

41. Dodev TS, Bowen H, Shamji MH, Bax HJ, Beavil AJ, McDonnell $\mathrm{JM}$, et al. Inhibition of allergen-dependent IgE activity by antibodies of the same specificity but different class. Allergy. 2015;70(6): $720-4$. Using a series of IgG and IgA antibodies with identical specificities, this report demonstrates that the specificity, but not the isotype determines the inhibitory activity of blocking antibodies.

42. Lambin P, Bouzoumou A, Murrieta M, Debbia M, Rouger P, Leynadier F, et al. Purification of human IgG4 subclass with allergen-specific blocking activity. J Immunol Methods. 1993;165(1):99-111.

43. James LK, Bowen H, Calvert RA, Dodev TS, Shamji MH, Beavil AJ, et al. Allergen specificity of $\operatorname{IgG}(4)$-expressing B cells in patients with grass pollen allergy undergoing immunotherapy. J Allergy Clin Immunol. 2012;130:663-70.

44. Kepley CL, Cambier JC, Morel PA, Lujan D, Ortega E, Wilson BS, et al. Negative regulation of FcepsilonRI signaling by FcgammaRII 
costimulation in human blood basophils. J Allergy Clin Immunol. 2000;106:337-48.

45. Burton OT, Logsdon SL, Zhou JS, Medina-Tamayo J, Abdel-Gadir A, Noval Rivas M, et al. Oral immunotherapy induces IgG antibodies that act through Fc $\gamma$ RIlb to suppress IgE-mediated hypersensitivity. J Allergy Clin Immunol. 2014;134:1310-7.

46. Ejrnaes AM, Svenson M, Lund G, Larsen JN, Jacobi H. Inhibition of rBet v 1-induced basophil histamine release with specific immunotherapy -induced serum immunoglobulin G: no evidence that FcgammaRIIB signalling is important. Clin Exp Allergy. 2006;36(3):273-82.

47. Cady CT, Powell MS, Harbeck RJ, Giclas PC, Murphy JR, Katial $\mathrm{RK}$, et al. IgG antibodies produced during subcutaneous allergen immunotherapy mediate inhibition of basophil activation via a mechanism involving both FcgammaRIIA and FcgammaRIIB. Immunol Lett. 2010;130:57-65.

48. van der Zee JS, van Swieten P, Aalberse RC. Serologic aspects of IgG4 antibodies. II. IgG4 antibodies form small, nonprecipitating immune complexes due to functional monovalency. J Immunol. 1986; 137:3566-71.

49. van der Neut Kolfschoten M, Schuurman J, Losen M, Bleeker WK, Martínez-Martínez P, Vermeulen E, et al. Anti-inflammatory activity of human $\mathrm{IgG} 4$ antibodies by dynamic Fab arm exchange. Science. 2007;317:1554-7.

50. Okayama Y, Hagaman DD, Woolhiser M, Metcalfe DD. Further characterization of FcgammaRII and FcgammaRIII expression by cultured human mast cells. Int Arch Allergy Immunol. 2001;124:155-7.

51. Kepley CL, Taghavi S, Mackay G, Zhu D, Morel PA, Zhang K, et al. Co-aggregation of FcgammaRII with FcepsilonRI on human mast cells inhibits antigen-induced secretion and involves SHIPGrb2-Dok complexes. J Biol Chem. 2004;279:35139-49.

52. Lee H, Kashiwakura J, Matsuda A, Watanabe Y, SakamotoSasaki T, Matsumoto K, et al. Okayama: activation of human synovial mast cells from rheumatoid arthritis or osteoarthritis patients in response to aggregated IgG through Fcgamma receptor I and Fcgamma receptor II. Arthritis Rheum. 2013;65: 109-19.

53. Zhao W, Kepley CL, Morel PA, Okumoto LM, Fukuoka Y, Schwartz LB. Fc gamma RIIa, not Fc gamma RIIb, is constitutively and functionally expressed on skin-derived human mast cells. J Immunol. 2006;177:694-701.

54. Sellge G, Barkowsky M, Kramer S, Gebhardt T, Sander LE, Lorentz A, et al. Interferon- $\gamma$ regulates growth and controls $\mathrm{Fc} \gamma$ receptor expression and activation in human intestinal mast cells. BMC Immunol. 2014;15:27.

55. Jones SM, Pons L, Roberts JL, Scurlock AM, Perry TT, Kulis M, et al. Clinical efficacy and immune regulation with peanut oral immunotherapy. J Allergy Clin Immunol. 2009;124:292-300.

56. Santos AF, James LK, Bahnson HT, Shamji MH, Couto-Francisco $\mathrm{NC}$, Islam S, et al. IgG4 inhibits peanut-induced basophil and mast cell activation in peanut-tolerant children sensitized to peanut major allergens. J Allergy Clin Immunol. 2015;135:1249-56.

57. Savilahti EM, Rantanen V, Lin JS, Karinen S, Saarinen KM, Goldis $\mathrm{M}$, et al. Early recovery from cow's milk allergy is associated with decreasing IgE and increasing IgG4 binding to cow's milk epitopes. J Allergy Clin Immunol. 2010;125:1315-21.

58. Ruiter B, Knol EF, van Neerven RJ, Garssen J, Bruijnzeel-Koomen CA, Knulst AC, et al. Maintenance of tolerance to cow's milk in atopic individuals is characterized by high levels of specific immunoglobulin G4. Clin Exp Allergy. 2007;37:1103-10.

59. Geroldinger-Simic M, Zelniker T, Aberer W, Ebner C, Egger C, Greiderer A, et al. Birch pollen-related food allergy: clinical aspects and the role of allergen-specific IgE and IgG4 antibodies. J Allergy Clin Immunol. 2011;127:616-22.

60. Stapleton NM, Einarsdóttir HK, Stemerding AM, Vidarsson G. The multiple facets of FcRn in immunity. Immunol Rev. 2015;268:253-68. 